\title{
ESTIMASI KEDALAMAN SESAR SORONG MENGGUNAKAN METODE DOUBLE DIFFERENCE
}

\author{
Cattleya Randi", Khairunnisa Nazhifah Yudyawati, Zidny Ilma Andromeda \\ Prodi Geofisika, Universitas Indonesia, Kota Depok, Jawa Barat \\ *Email: cattleyaeyaa@gmail.com
}

\begin{abstract}
ABSTRAK
Papua merupakan wilayah dengan tingkat seismisitas tinggi yang diakibatkan oleh aktivitas tektonik yang kompleks. Terdapat beberapa sesar aktif di wilayah Papua dan mencatat sejumlah sejarah kegempaan di wilayah tersebut salah satunya adalah Sesar Sorong. Untuk melalukan analisis estimasi kedalaman Sesar Sorong diperlukan keakuratan posisi hiposenter. Salah satu metode untuk merelokasi hiposenter adalah metode double difference, melakukan relokasi hiposenter dengan metode double difference diharapkan mampu meningkatkan keakuratan posisi hiposenter. Prinsip dari metode double difference adalah residual time dari waktu tempuh yang diamati dan hasil perhitungan antara dua event gempa bumi yang berdekatan pada stasiun pencatat yang sama, dengan syarat jarak antar event harus lebih dekat dari pada jarak event ke stasiun pencatat. Data gempabumi yang digunakan sebanyak 2.374 kejadian dari katalog BMKG yang tercatat pada 15 stasiun INA-Tews. Berdasarkan hasil analisis sesar wilayah Papua di dapatkan bahwa Sesar Sorong Barat (10-29 km), Sesar Sorong Utara (3-22 km), dan Sesar Sorong Timur (3-32 km). Hasil relokasi menggunakan metode doule difference cukup efektif karena menunjukkan peningkatan kualitas bila dilihat dari distribusi residual yang diperoleh setelah relokasi dibandingkan residual sebelum relokasi.
\end{abstract}

Kata kunci: Sesar Sorong, relokasi hiposenter, metode double difference

\begin{abstract}
Papua is a region with a high level of seismicity caused by complex tectonic activity. There are several active faults in Papua and recorded a number of seismic history in the region, one of them is Sesar Sorong. To pass the analysis of Sorong Fault depth estimation, the accuracy of the hypocenter position is required. One method to relocate the hypocenter is the double difference method, hypocenter relocation by double difference method is expected to improve the accuracy of the hypocenter position. The principle of the double difference method is the residual time of the observed travel time and the calculation results between two adjacent earthquake events at the same recording station, provided that the distance between events must be closer than the event distance to the recording station. Data on the earthquake used as many as 2,374 events from the BMKG catalog recorded on 15 stations INA-Tews. Based on the results of the analysis of the Papua region faults, it was found that the North Sorong Fault (3-35 km), West Sorong Fault (10-38 km), and East Sorong Fault $(3-40 \mathrm{~km})$ were classified into shallow faults because of the depth of $<60$ $\mathrm{km}$. The relocation result using doule difference method is quite effective because it shows the improvement of quality when viewed from residual distribution obtained after relocation compared to residual before relocation.
\end{abstract}

Keywords: Fault Sorong, hyposenter relocation, double difference method 


\section{PENDAHULUAN}

Papua merupakan salah satu daerah yang memiliki kondisi tektonik yang kompleks di dunia. Secara tektonik, wilayah Papua merupakan wilayah pertemuan 4 buah lempeng tektonik yaitu lempeng Australia, lempeng Pasifik, lempeng Laut Filipina, dan lempeng Eurasia. Benturan lempeng-lempeng tersebut menghasilkan gerak patahan-patahan kombinasi thrusting dan geser di seluruh pulau Papua salah satu sesarnya adalah adanya Sesar Sorong. Sesar Sorong merupakan sistem sesar mendatar mengiri yang terletak di bagian utara Papua, memanjang hingga $1.000 \mathrm{~km}$ dari bagian timur pulau hingga bagian Kepala Burung, Papua. Sesar Sorong merupakan suatu sistem sesar yang aktif sejak Miosen Akhir. Sesar Sorong ini terbentuk akibat benturan lempeng Benua Australia dengan Lempeng Samudera Pasifik. Lempeng Benua Australia bergerak dari Selatan ke Utara. Sedangkan Lempeng Samudera Pasifik bergerak dari Timur ke Barat. Model terbaru mengindikasikan bahwa sesar ini merotasi daerah Kepala Burung, Papua, termasuk Cekungan Salawati, ke arah barat. Pergerakan sesar tersebut merupakan pergerakan rotasi dan translasi yang memisahkan Cekungan Salawati dari daerah Kepala Burung, Papua dengan tinggian batuan dasar sebagai batas cekungan (Baldwin dkk., 2012)

Salah satu sejarah kegempabumian yang diakibatkan oleh aktivitas Sesar Sorong yaitu bencana gempabumi 6,8 SR mengguncang Kota Sorong, Provinsi Papua Barat pada Kamis (24/9/2015) pukul 22.53.28 WIB. Sumber gempa di daerah sesar Sorong. Gempa tidak berpotensi tsunami. Guncangan gempa dirasakan kuat selama sekitar 15 detik oleh masyarakat Kota Sorong. Masyarakat berhamburan keluar rumah. Gempabumi ini telah menimbulkan dampak di Kota Sorong, Kabupaten Sorong dan Kabupaten Raja Ampat, Provinsi Papua Barat. Dampak terparah adalah di Kota Sorong karena padat penduduk dan bangunan. Data sementara dilaporkan 2.889 unit bangunan rusak, dimana 2.437 unit di Kota Sorong, 408 unit di Kabupaten Sorong, dan 44 unit di Kabupaten Raja Ampat. Berdasarkan laporan Walikota Sorong, L. Jitmau, korban luka 45 jiwa dan 2.437 unit bangunan rusak, dimana 40 jiwa luka ringan, 5 jiwa luka sedangberat, 1.240 unit bangunan rusak ringan, 238 rusak sedang, dan 869 unit rusak berat di Kota
Sorong. Selain itu fasilitas umum juga terkena dampaknya, antara lain: 14 unit gereja, 7 unit sekolah, 3 unit masjid, 3 ruas jalan, 2 unit tower, 2 unit fasilitas kesehatan, 1 unit ruang tunggu bandara, 1 unit pelabuhan, dan 4 unit kantor (BNPB, 2015).

Untuk melakukan analisis kedalaman Sesar Sorong diperlukan penentuan hiposenter yang akurat. Masalah terbesar dari analisis ini adalah adanya ketidakpastian lokasi hiposenter yang sering kali jauh dari dimensi patahan sumber gempabumi tersebut, hal ini menyebabkan kesulitan dalam interpretasi struktur geologi dengan baik sehingga diperlukan adanya relokasi hiposenter. Akurasi dari sumber gempabumi dipengaruhi oleh beberapa faktor yaitu banyaknya gelombang yang terekam pada stasiun, struktur kecepatan gelombang seismik, akurasi pembacaan waktu tiba, dan geometri stasiun pengamat (Sunardi dkk., 2012).

Salah satu teknik untuk merelokasi hiposenter gempabumi adalah dengan algoritma double difference (perbedaan ganda). Relokasi ini diharapkan mampu meningkatkan keakuratan sumber gempabumi yang dapat dijadikan acuan dalam analisis sesar (Puspito, dan Nanang, 2009). Penelitian ini bertujuan untuk menganalisis Sesar Sorong yang berada di Papua dengan menggunakan metode double difference.

\section{METODE PENELITIAN}

Penelitian ini menggunakan data gempabumi BMKG yang terjadi di wilayah Papua dengan batasan koordinat $129.86^{\circ} \mathrm{BT}-140.71^{\circ} \mathrm{BT}$ dan 1.36LU - 9.49LS (BMKG, 2017). Data diambil dari tanggal 01 Januari 2010 sampai dengan 16 Agustus 2017. Dengan stasiun pengamat sebanyak 15 yang tersebar di wilayah Papua.

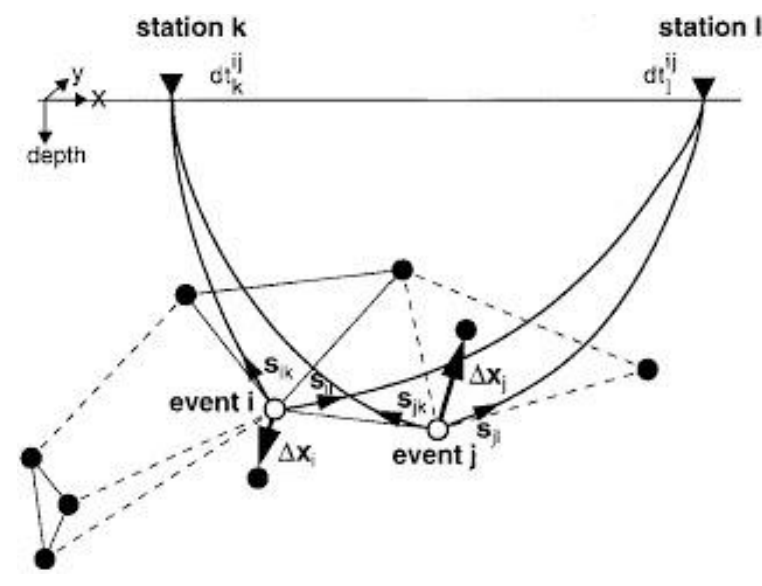




\section{Gambar 1. Algoritma double difference}

Prinsip metode ini adalah jika jarak persebaran hiposenter antara dua gempabumi sangat kecil dibandingkan dengan jarak antara stasiun gempabumi, maka raypath dan waveform kedua gempabumi dapat dianggap mendekati sama. Dengan asumsi ini, maka selisih waktu tempuh antara kedua gempabumi yang terekam pada satu stasiun yang sama dapat dianggap hanya sebagai fungsi jarak antara kedua hiposenter. Sehingga kesalahan model kecepatan bisa diminimalisasi tanpa menggunakan koreksi stasiun (Waldhauser dan Ellsworth, 2000).

Lingkaran hitam dan putih menunjukkan hiposenter yang dihubungkan dengan pusat gempabumi disekitarnya dengan data korelasi silang (garis utuh) atau katalog gempabumi (garis putus-putus). Lingkaran putih menunjukkan gempabumi i dan $\mathrm{j}$ terekam pada stasiun yang sama $\mathrm{k}$ dan 1 dengan selisih waktu tempuh dtijl dan dtijk serta vektor slowness-nya s. Posisi dua event tersebut jaraknya jauh lebih kecil dibandingkan jarak dua event ke dua stasiun pencatat gempabumi, hal tersebut menyebabkan raypath cenderung sama. Vektor relokasi ditunjukkan oleh Gambar 1 (Waldhauser dan Ellsworth, 2000).

Residual time antara pengamatan dan perhitungan $(\Delta \mathrm{d})$ merupakan perbedaan waktu tempuh observasi dan kalkulasi antara dua event gempabumi (Waldhauser dan Ellsworth, 2000) dan dapat dinyatakan dalam pers. (1) :

$$
\mathrm{D}^{\mathrm{i} j} \mathrm{k}=\left(\mathrm{t}^{\mathrm{i}} \mathrm{k}-\mathrm{t}^{\mathrm{j}} \mathrm{k}\right)^{\mathrm{obs}}-\left(\mathrm{t}^{\mathrm{i}} \mathrm{k}-\mathrm{t}^{\mathrm{j}} \mathrm{k}\right)^{\mathrm{cal}}
$$

Pers. (1) adalah persamaan double difference. Merupakan waktu tempuh gelombang seismik ke stasiun $\mathrm{k}$ akibat gempabumi $\mathrm{i}$ dan merupakan waktu tempuh gelombang seismik ke stasiun $\mathrm{k}$ akibat gempabumi $\mathrm{j}$. Selanjutnya pers. (1) dapat ditulis dalam bentuk :

$$
\Delta d=\frac{\partial t^{i} k}{\partial m} \Delta m^{i}-\frac{\partial t^{j} k}{\partial m} \Delta m^{j}
$$

Apabila dilakukan penguraian parameter perubahan model hiposenter $(\Delta \mathrm{m})$, pers. (2) selanjutnya dapat dinyatakan menjadi :

$$
\begin{aligned}
& \Delta d=\frac{\partial t^{i} k}{\partial x} \Delta x^{i}+\frac{\partial t^{i} k}{\partial y} \Delta y^{i}+\frac{\partial t^{i} k}{\partial z} \Delta z^{i}+\Delta t_{o}^{i}- \\
& \frac{\partial t^{j} k}{\partial x} \Delta x^{j}-\frac{\partial t^{j} k}{\partial y} \Delta y^{j}-\frac{\partial t^{j} k}{\partial z} \Delta z^{j}-\Delta t_{o}^{i}
\end{aligned}
$$

Pers. (3) tersebut berlaku dalam satu klaster gempabumi. Apabila dinyatakan dalam bentuk matriks menjadi:

$\mathrm{W} \Delta \mathrm{d}=\mathrm{WG} \Delta \mathrm{m}$

Dimana $\Delta \mathrm{d}$ adalah matriks waktu residu berdimensi $\mathrm{m} \times 1 . \mathrm{m}$ dan $\mathrm{g}$ berturut-turut merupakan jumlah data observasi double difference dan matriks jacobi yang berdimensi $\mathrm{m} \times 4 \mathrm{n} . \mathrm{n}$ dan $\Delta \mathrm{m}$ berturut-turut adalah dxj jumlah gempabumi dan matriks perubahan model yang berdimensi $4 \mathrm{n} \times 1$, sedangkan $\mathrm{W}$ merupakan matriks diagonal yang menjadi pembobotan dalam persamaan perhitungan waktu tempuh gelombang. Proses iterasi terus dilakukan untuk memperbaiki parameter model hiposenter sehingga selisih waktu pengamatan dan waktu perhitungan akan mendekati nol. Pers. (5) berikut merupakan proses untuk memperbaiki parameter model dua hiposenter (Sunardi dkk., 2012).

$$
\begin{aligned}
\mathrm{x}^{\mathrm{i}}{ }_{1}=\mathrm{x}_{0}{ }_{0}+\Delta \mathrm{x}^{\mathrm{i}}, \mathrm{y}^{\mathrm{i}}{ }_{1}=\mathrm{y}^{\mathrm{i}}{ }_{0}+\Delta \mathrm{y}^{\mathrm{i}}, \mathrm{z}^{\mathrm{i}}{ }_{1} \\
=\mathrm{z}_{0}{ }_{0}+\Delta \mathrm{z}^{\mathrm{i}}, \mathrm{t}_{01}^{\mathrm{i}}=\mathrm{t}^{\mathrm{i}}{ }_{00}+\Delta \mathrm{t}_{0}{ }^{\mathrm{i}} \\
\mathrm{x}^{\mathrm{j}}{ }_{1}=\mathrm{x}^{\mathrm{j}}{ }_{0}+\Delta \mathrm{x}^{\mathrm{j}}, \mathrm{y}^{\mathrm{j}}{ }_{1}=\mathrm{y}^{\mathrm{j}}{ }_{0}+\Delta \mathrm{y}^{\mathrm{j}}, \mathrm{z}^{\mathrm{j}}{ }_{1} \\
=\mathrm{z}_{0}{ }_{0}+\Delta \mathrm{z}^{\mathrm{j}}, \mathrm{t}_{01}{ }_{01}=\mathrm{t}^{\mathrm{j}}{ }_{00}+\Delta \mathrm{t}_{0}{ }^{\mathrm{j}}
\end{aligned}
$$

HypoDD merupakan program untuk merelokasi hiposenter dengan algoritma double difference. Posisi hiposenter pada awalnya ditentukan dengan menggunakan metode Geiger . Lokasi pusat gempabumi yang ditentukan tentunya akan mengandung kesalahan yang berhubungan dengan struktur kecepatan yang tidak termodelkan. Algoritma double difference dapat meningkatkan akurasi dengan cara menghilangkan efek yang berhubungan dengan struktur kecepatan yang tidak termodelkan. Program hypoDD dapat mengatasi orientasi patahan sehingga memberikan pandangan yang lebih jelas terhadap Sesar Sorong (Waldhauser dan Ellsworth, 2000).

Tahap pertama penelitian adalah menyiapkan data arrival time dari katalog BMKG dari tahun 2010-2017 dalam bentuk format txt. Langkah selanjutnya adalah konversi data dengan format txt menjadi format pha dengan program phyton. Selanjutnya data tersebut menjadi input dalam menggunakan program ph2dt yang dijalankan menggunakan Cygwin. Hasil output dari program ph2dt merupakan file-file (file.dt, event.dat, stasiun.dat) yang digunakan sebagai masukan untuk mengolah data menggunakan 
program hypoDD. Gambar 2 (a) menunjukkan diagram alir penggunaan $\mathrm{ph} 2 \mathrm{dt}$.

Kemudian tahap kedua yaitu mengolah data dari hasil ph2dt menggunakan program hypoDD yang dijalankan dengan Cygwin. Hasil output dari program hypoDD yaitu HypoDD.res (untuk melihat nilai residual dari hasil relokasi yang di dapatkan, biasanya data dari HypoDD.res di olah di excel untuk melihat nilai residual yang di tunjukan dengan histogram biasanya mendekati nol), HypoDD.reloc (untuk melihat hasil relokasi, hasil relokasi berupa lintang, bujur, dan kedalaman selanjutnya dapat di plot di GMT untuk pemetaan), HypoDD.sta (untuk melihat

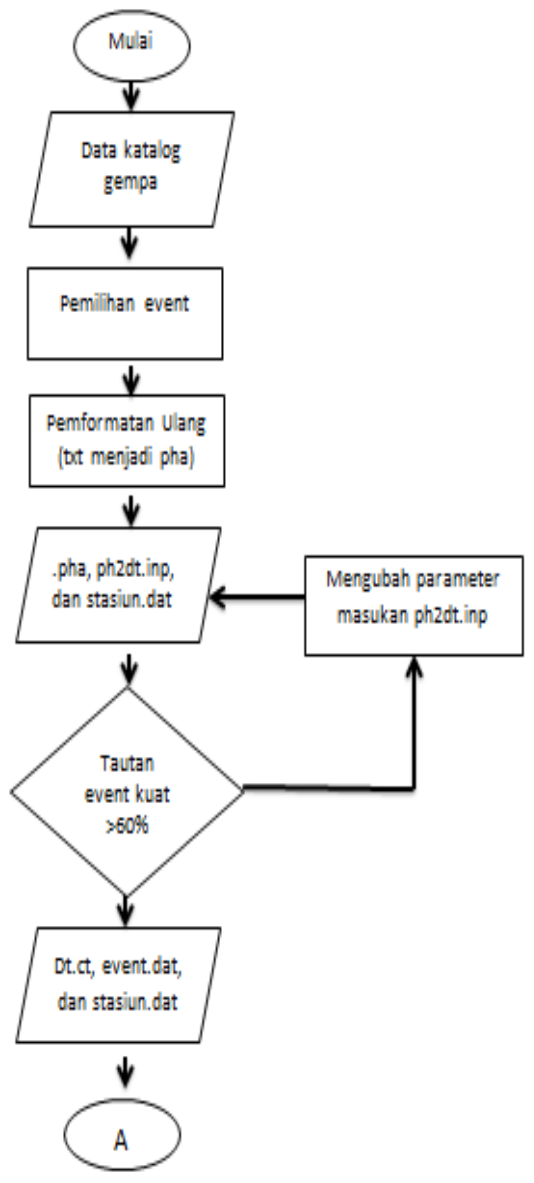

stasiun-stasiun yang mencatat), hypoDD.loc (untuk melihat data gempa sebelum direlokasi). Gambar 2(b) menunjukkan diagram alir penggunaan hypoDD.

Tahap akhir adalah pembuatan peta seismisitas dan irisan penampang dari wilayah yang ingin di analisis dengan menggunakan software GMT. Dalam pembuatan peta seismitas dan irisan penampang dibutuhkan input berupa magnitudo, koordinat, dan kedalaman gempabumi dari hasil pengolahan menggunakan hypoDD (hypoDD.reloc dan hypoDD.loc). Kemudian dibuat file dalam format bat untuk menjalankan GMT.

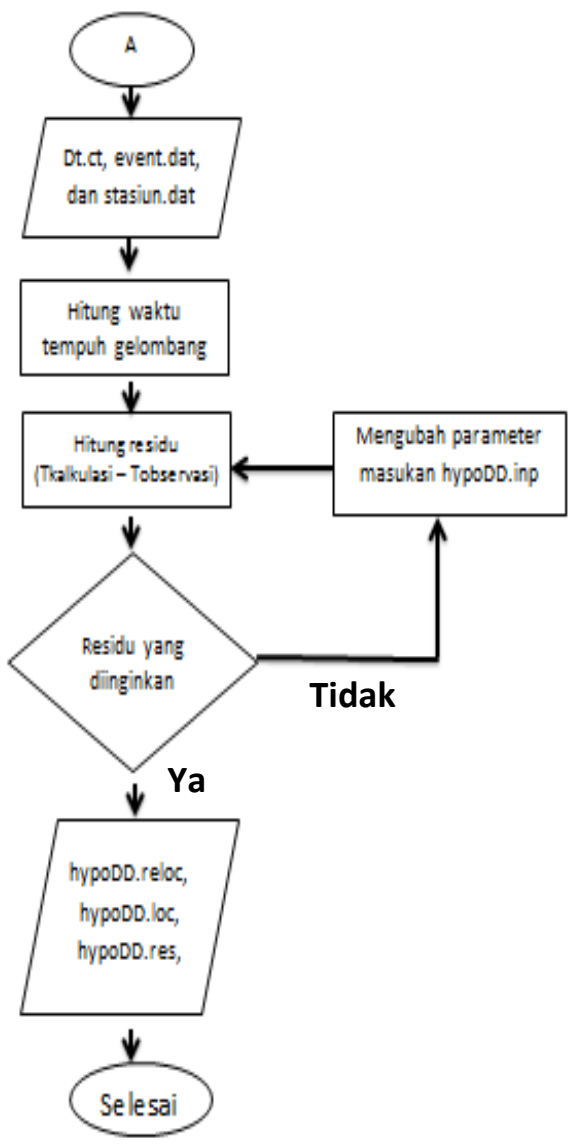

Gambar 2. (a) Diagram alir penggunaan ph2dt. (b) Diagram alir penggunaan hypoDD. 


\section{HASIL DAN PEMBAHASAN}

Untuk menguji hasil relokasi, pada penelitian ini dilakukan pengujian distribusi frekuensi residual time untuk sebelum relokasi dan sesudah relokasi menggunakan grafik histogram. Dari Gambar 3 (a) nampak bahwa nilai-nilai residual setelah dilakukan relokasi hiposenter menggunakan hypoDD lebih banyak yang mendekati nol dibandingkan nilai-nilai residual sebelum dilakukan relokasi yang ditunjukkan oleh Gambar 3 (b). Dengan demikian dapat dikatakan bahwa relokasi hiposenter gempa bumi dengan menggunakan hypoDD memberikan nilai residual yang lebih baik.

a)

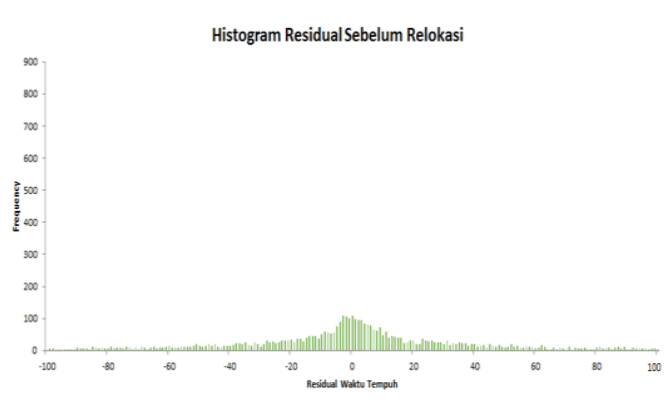

b)

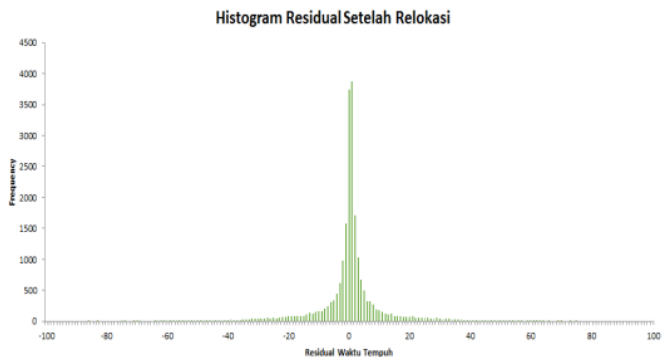

Gambar 3. (a) Histogram residual sebelum relokasi. (b) Histogram residual setelah relokasi.

Untuk melakukan analisis Sesar Sorong dilakukan analisis irisan penampang vertikal untuk sebaran posisi gempabumi mulai dari A-A'sampai C-C' yang ditunjukkan oleh
Gambar 4. Hasil irisan penampang vertikal A-A' yang melewati Sesar Sorong Barat memperlihatkan kedalaman sesar tersebut berkisar 10-29 km yang ditunjukkan oleh Gambar 5 dengan besar magnitudo antara $3.3 \mathrm{Mw}$ hingga $4.4 \mathrm{Mw}$. Hasil irisan penampang vertikal B-B' yang melewati Sesar Sorong Utara memperlihatkan kedalaman sesar tersebut berkisar 3-22 km yang ditunjukkan oleh Gambar 6 dengan besar magnitudo antara $3.5 \mathrm{Mw}$ hingga 5.0Mw. Sedangkan Gambar 7 adalah hasil irisan penampang vertikal C-C' yang melewati Sesar Sorong Timur memperlihatkan kedalaman sesar tersebut berkisar 3-32 km dengan besar magnitudo antara $2.6 \mathrm{Mw}$ hingga 6.0Mw.

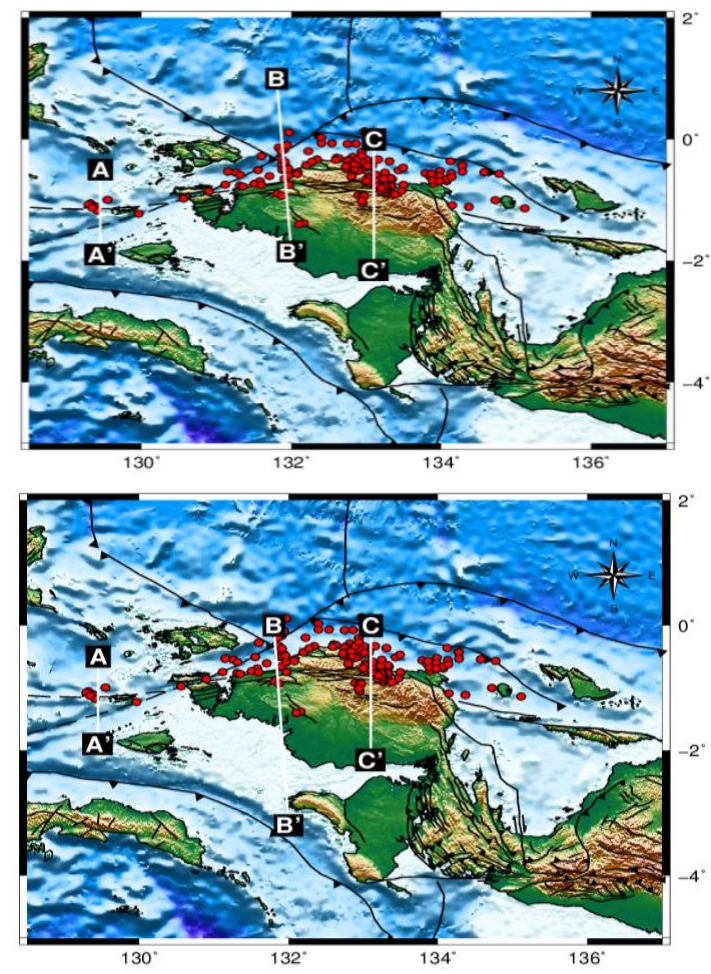

Gambar 4. Peta irisan penampang dari AA'sampai C-C' 

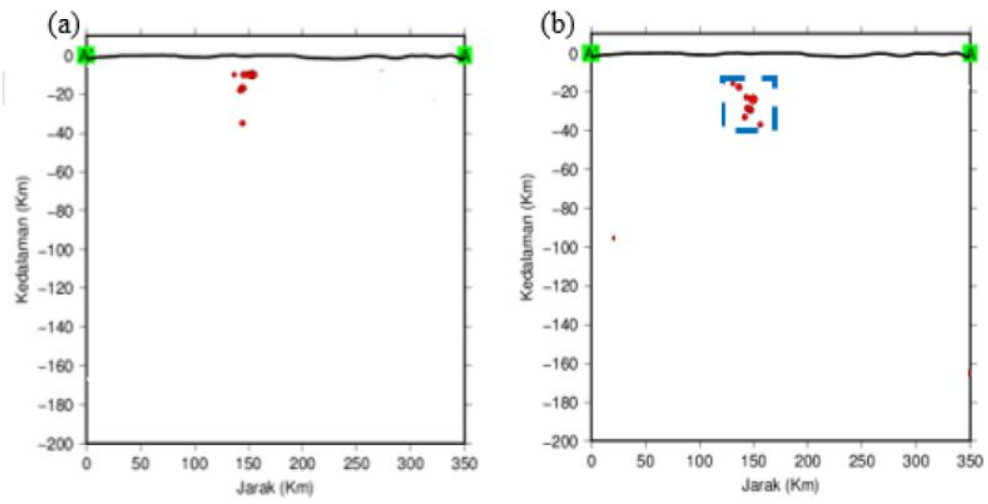

Gambar 5. a) Irisan penampang vertikal A-A'sebelum relokasi dan b) Irisan penampang vertikal A-A'setelah relokasi. Terdapat cluster gempabumi akibat Sesar Sorong sebelah Barat (kotak biru).

(a)

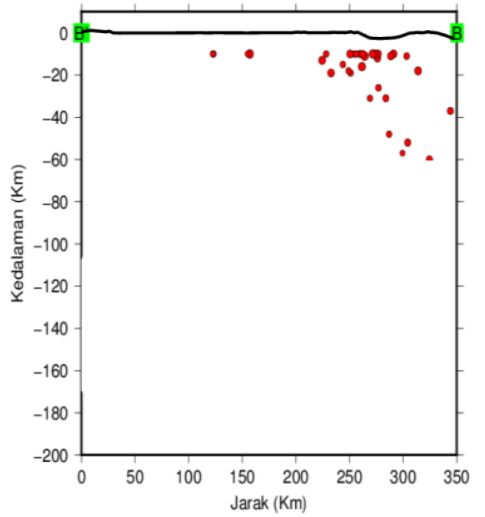

(b)

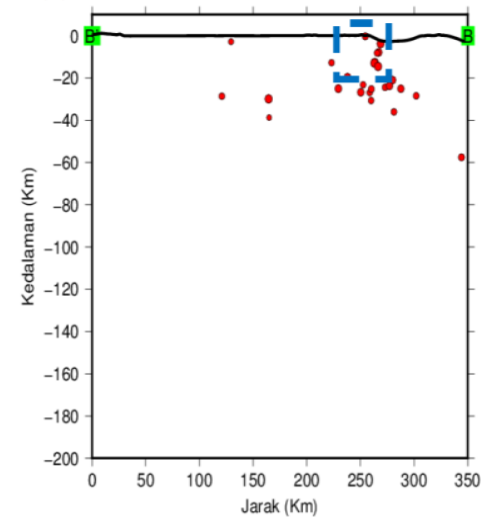

Gambar 6. a) Irisan penampang vertikal B-B'sebelum relokasi dan b) Irisan penampang vertikal B-B'setelah relokasi. Terdapat cluster gempabumi akibat Sesar Sorong sebelah Utara (kotak biru).

(a)

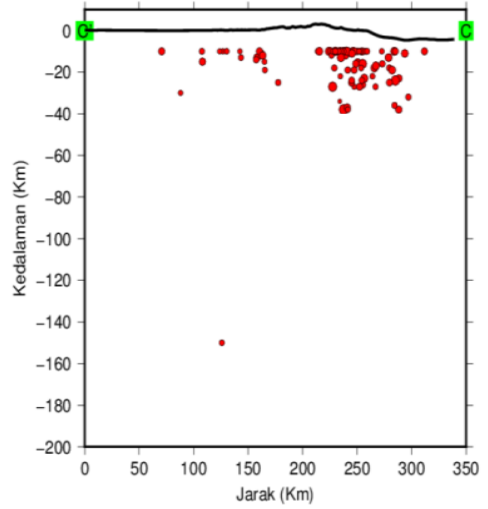

(b)

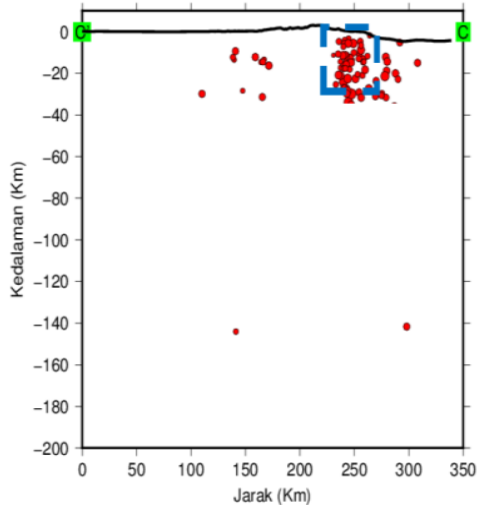

Gambar 7. a) Irisan penampang vertikal C-C'sebelum relokasi dan b) Irisan penampang vertikal C-C'setelah relokasi. Terdapat cluster gempabumi akibat Sesar Sorong sebelah Timur (kotak biru). 
Dari seluruh analisis irisan penampang Sesar Sorong selanjutnya dilakukan perbandingan kedalaman sesar dengan hasil penelitian dari Tim 9 dan Sabtaji. Hasil yang didapatkan oleh Tim 9 kedalaman maksimal Sesar Sorong berkisar antara 29 - 32 km (Irsyam dkk., 2010). Berdasarkan penelitian ini dan penelitian Sabtaji (2014) didapatkan kedalaman gempabumi lebih bervariasi dibandingkan Tim 9. Untuk lebih detailnya, perbandingan dapat dilihat pada Tabel 1.

Tabel 1. Perbandingan hasil kedalaman Sesar Sorong

\begin{tabular}{|l|c|c|c|}
\hline $\begin{array}{c}\text { Bagian } \\
\text { Sesar } \\
\text { Sorong }\end{array}$ & $\begin{array}{c}\text { Tim 9 } \\
\text { (Irsyam } \\
\text { et al, } \\
\text { 2010) }\end{array}$ & $\begin{array}{c}\text { (Sabtaji, } \\
\text { 2015) }\end{array}$ & $\begin{array}{c}\text { Hasil } \\
\text { Penelitian }\end{array}$ \\
\hline $\begin{array}{l}\text { Sorong } \\
\text { Barat }\end{array}$ & $3-18 \mathrm{~km}$ & $9-26 \mathrm{~km}$ & $10-29 \mathrm{~km}$ \\
\hline $\begin{array}{l}\text { Sorong } \\
\text { Utara }\end{array}$ & - & $5-24 \mathrm{~km}$ & $3-22 \mathrm{~km}$ \\
\hline $\begin{array}{l}\text { Sorong } \\
\text { Timur }\end{array}$ & $3-18 \mathrm{~km}$ & $7-29 \mathrm{~km}$ & $3-32 \mathrm{~km}$ \\
\hline
\end{tabular}

Pada Gambar 8 adalah data mekanisme fokus yang lebih menambah informasi seismotektonik Sesar Sorong, data mekanisme fokus tersebut didapat dari Global CMT Catalog Search (2018). Berdasarkan Tim 9 dan Sabtaji mekanisme fokus yang berada di sekitar Sesar Sorong adalah sesar mendatar (strike slip fault). Pada hasil penelitian ini pun menunjukkan hasil bahwa Sesar Sorong merupakan sesar mendatar (strike slip fault).

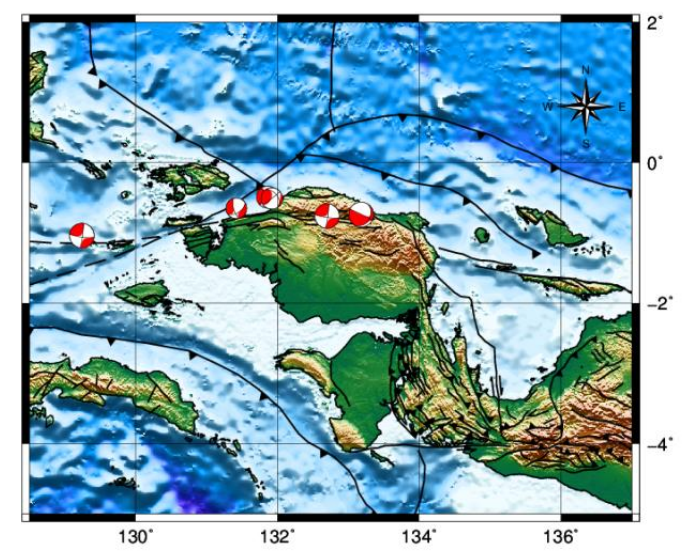

Gambar 8. Peta mekanisme fokus Sesar Sorong

\section{KESIMPULAN}

Berdasarkan hasil analisis kedalaman Sesar Sorong menggunakan metode double difference didapatkan kesimpulan sebagai berikut :

- Berdasarkan hasil analisis Sesar Sorong di dapatkan bahwa Sesar Sorong Barat (10-29 km), Sesar Sorong Utara (3-22 $\mathrm{km}$ ), dan Sesar Sorong Timur (3-32 $\mathrm{km})$, sesar ini tergolong ke dalam sesar dangkal karena kedalamannya $<60 \mathrm{~km}$.

- Mekanisme fokus yang berada di sekitar Sesar Sorong adalah sesar mendatar (strike slip fault).

- Relokasi menggunakan metode double difference menunjukkan peningkatan kualitas bila dilihat dari distribusi residual yang diperoleh setelah relokasi dibandingkan residual sebelum relokasi.

\section{UCAPAN TERIMA KASIH}

Penulis mengucapkan terimakasih kepada BMKG yang telah menyediakan data repo gempabumi. Penulis juga mengucapkan terimakasih kepada Dr. Eng. Supriyanto, M.Sc selaku selaku ketua program studi Geofisika yang telah memberikan dukungan dan kepada segenap keluarga PUSLITBANG BMKG Jakarta Pusat terutama kepada Bapak Arif Rachman Hakim, S.Tr dan Tio Azhar Prakoso Setiadi, S.Tr atas kritik dan saran dalam pelaksanaan hingga pembuatan laporan ini.

\section{DAFTAR PUSTAKA}

Baldwin, S. E. 2012. Annual Reviews Earth Planet Science. 40. 495.

Badan Nasional Penanggulangan Bencana. Info bencana p.1 p.4. 2015.

Sunardi, B., Rohadi, S., Masturyono, S., Widiyantoro, P., Susilanto, Hardy T., dan Setyonegoro, T. 2012. Jurnal Meteorologi dan Geofisika 179-188.

Puspito dan Nanang, T. 2009. Jurnal Matematika dan Sains, 20-39. 
BMKG earthquake repository, (http://repogempa.bmkg.go.id/query. php, diunduh pada 21 Agustus 2017)

Waldhauser, F., dan Ellsworth, W. L. 2000. Bull. Seism. Soc. Am 90. 1353.

Rahmawati, D. N. 2016. Estimasi Model Kecepatan 1-D Hasil Relokasi Gempa Bumi Wilayah Maluku Utara Dengan Menggunakan Metode Double Difference. Tesis, Fakultas MIPA, Institut Teknologi Sepuluh November.

Irsyam, M., Sengara, W., Aldiamar, F., Widiyantoro, S., Triyoso, W., Hilman, D., Kertapati, I., Meilano, Suhardjono, M., Asrurifak, dan Ridwan M. 2010. Ringkasan Hasil Studi Tim Revisi Peta Gempabumi Indonesia 2010, Bandung.

Sabtaji, A., dan Nugraha, A. D. 2014. 1-D Seismic Velocity Model and Hypocenter Relocation using Double Difference Method around West Papua Region. Proceeding of The 4th International Symposium on Earthquake and Disaster Mitigation. Bandung.

Global CMT Catalog Search, (http://www.globalcmt.org/CMTsearch.ht ml, diunduh pada 10 Maret 2018). 